\title{
Kokoaan suurempi? Suomen ja Luxemburgin turvallisuusneuvostokampanjat
}

TARJA SEPPÄ ANNI TERVO

\section{JOHDANTO}

YK:n turvallisuusneuvoston vaihtuvan jäsenen paikka on tavoiteltu. Paikka tuo valtiolle määritelmällisesti lisääntyviä mahdollisuuksia verkostoitumiseen sekä lisääntyneen kansainvälispoliittisen näkyvyyden vuoksi vahvemman statuksen. Turvallisuusneuvosto tekee YK:n jäsenvaltioita sitovia päätöksiä omaten täten ylivertaista poliittista auktoriteettia kansainvälisessä politiikassa. YK:ta ja turvallisuusneuvostoa on kuitenkin myös kritisoitu laajasti siitä, ettei se ole kyennyt toimimaan kansainvälisen rauhan ja turvallisuuden edistämiseksi toivotulla tavalla (ks. esim. von Einsiedel-Bosetti 2016). YK:n yleiskokous valitsee vuosittain viisi turvallisuusneuvoston vaihtuvaa jäsentä kahden vuoden pituiseksi määräajaksi ${ }^{1}$. Turvallisuusneuvoston vaihtuvan jäsenen paikka ei ole julkisuudessa eikä akateemisessa tutkimuksessa ollut erityisen kiinnostava tutkimuskohde, vaikka yleiskokouksen vuosittaiset äänestykset ilmentävät korkeinta YK-diplomatiaa (ks. esim. Ekengren ja Möller 2020a).

Suomi haki vaihtuvan jäsenen paikkaa vuonna 2012 kaudeksi 2013-2014 Länsi-Eurooppa ja muut maat -ryhmässä (WEOG, Western European and Others Group). Suomen lisäksi myös Australia ja Luxemburg olivat ilmoittaneet halukkuutensa ehdokkuuteen tarjolla olleisiin kahteen paikkaan. Luxemburg ilmoitti ehdokkuudestaan vuonna 2001, Suomi vuonna 2002 ja Australia vuonna 2008. Ensimmäisellä äänestyskierroksella lokakuussa 2012 Australia sai 140, Luxemburg 128 ja Suomi 108 ääntä, minkä johdosta Australia valittiin ensimmäisellä äänestyskierroksella. Toisella äänestyskierroksella Luxemburg sai 131 ja Suomi 62 ääntä (YK 2012). Suomi jäi valitsematta, mikä oli vastoin monien oletuksia (ks. esim. IPI 2013).

Miksi valtiot hakevat vaihtuvan jäsenen paikkaa turvallisuusneuvostossa, jota usein kuvataan pysyvien jäsenten hallitsemaksi? Millaisia odotuksia valtioilla on turvallisuusneuvoston vaihtuvan jäsenen paikan suhteen? Esitettyään kiinnostuksensa vaihtuvan jäsenen paikkaan valtioiden on ryhdyttävä kampanjoimaan valintansa puolesta. Miten ne toteuttavat kampanjansa ja miksi toiset kampanjat ovat menestyksellisempiä kuin toiset?

Näitä kysymyksiä on tutkittu pohjoismaisessa tutkimusprojektissa The Quest for Power in International Politics: Campaigns by and Selection of Non-Permanent Members to the United Nations Security Council (2017-2020), jonka on rahoittanut Ruotsin tutkimusneuvosto (Vetenskapsrådet). Projektissa on ollut mukana tutkijoita Ruotsista (Göteborgin yliopisto), Islannista (Islannin yliopisto) ja Suomesta (Tampereen yliopisto).

Aloite tutkimusprojektiin tuli Ruotsilta. Kun Ruotsi vuonna 2016 voitti Alankomaat ja tuli valituksi turvallisuusneuvoston vaihtuvaksi jäseneksi kaudelle 2017-2018 ${ }^{3}$, oli tapahtunut sekä 
Ruotsille että muille Pohjoismaille helpotus. Ruotsin valinta mursi ajatuksen esitetystä Pohjoismaiden kollektiivisesta epäonnistumisesta ja siitä, että ne olisivat menettämässä erityisen asemansa YK:n jäsenvaltioiden keskuudessa (ks. esim. IPI 2013). Islanti oli hävinnyt vuonna 2008 (turvallisuusneuvostokausi 2009-2010) vaihtuvan turvallisuusneuvostopaikan Itävallalle ${ }^{4}$ ja Suomi mainitusti Luxemburgille (kausi 2013-2014) (ks. Ekengren ja Möller 2020d).

Tässä artikkelissa käsitellään tutkimusprojektin kiinnostuksen kohteena olleita syitä siihen, miksi valtiot tavoittelevat turvallisuusneuvoston vaihtuvan jäsenen paikkaa ja miten ne kampanjoivat paikan saadakseen. Tähän liittyen artikkelissa, joka perustuu edellä mainitun projektin vielä julkaisemattomaan käsikirjoitukseen (Piiparinen ym. 2020), keskitytään erityisesti esittelemään Suomen ja Luxemburgin turvallisuusneuvostokampanjoita. Analyysimme perusteella esitämme, kuinka Suomen kampanja ei epäonnistunut usein syyksi esitetyn liiallisen "besserwissermäisen" ihmisoikeus- ja tasa-arvopoliittisen painotuksen vuoksi. Sen sijaan kampanjan epäonnistumiselle on löydettävissä useita toisistaan erillisiä syitä, kuten ristiriitainen maakuva, epäselvät kampanjaviestit ja "business as usual" -asenne.

\section{MIKSI VALTIOT HAKEVAT YK:N TURVALLISUUSNEUVOSTON VAIHTUVIKSI JÄSENIKSI JA MITÄ NE ODOTTAVAT JÄSENYYSKAUDELTA?}

Teoreettinen keskustelu siitä, miksi valtiot haluavat turvallisuusneuvoston vaihtuvan jäsenen paikalle ja miten ne ovat toteuttaneet kampanjansa on ollut suhteellisen vähäistä (Ekengren ja Möller 2020a; 2020b). Pohjoismaisen tutkimusprojektin tarkoituksena on ollut tuottaa teoreettista ja empiiristä tutkimustietoa edellä mainituista tutkimuskysymyksistä. Tutkimusprojektin tavoitteena on ollut myötävaikuttaa keskusteluun vallan (engl. power) ja vaikutusvallan (influence) käsitteistä kansainvälisessä politiikassa erityisesti suhteessa YK:n turvallisuusneuvostoon sekä siihen liittyvään poliittiseen kampanjointiin.

Tutkimus on toteutettu kahdessa osassa. Sen ensimmäinen osa vastaa kysymykseen miksi valtiot haluavat tavoitella vaihtuvan jäsenen paikkaa ja mitä ne odottavat jäsenyyskaudelta. Teoreettisen osan perusteella ${ }^{5}$ (Ekengren ja Möller 2020b) tutkimuksessa argumentoidaan, kuinka turvallisuusneuvoston vaihtuvan jäsenen paikka kiinnostaa valtioita 1) mahdollisuutena merkitykselliseen toimintaan kansainvälisissä suhteissa ja/tai mahdollisuutena vaikuttaa tehtäviin päätöksiin; 2) mahdollisuutena laajentaa ja kasvattaa omia verkostojaan ja 3) mahdollisuutena lisätä omaa statustaan. Nämä kolme teoreettista lähtökohtaa ohjasivat New Yorkissa tehtyä puhelinhaastattelututkimusta ${ }^{6}$ maiden pysyvien edustustojen diplomaateille syyskuun 2017 ja huhtikuun 2018 välisenä aikana. Lisäksi tehtiin toinen haastattelukierros, joka mahdollisti kolme pareittain tehtävää vertailua menestyksellisten ja ei-menetyksellisten, pohjoismaisten ja ei-pohjoismaisten WEOG-ryhmän kandidaattien eli Islannin ja Itävallan, Suomen ja Luxemburgin sekä Ruotsin ja Alankomaiden välillä. Mainitut maat valikoituivat pareittain tehtäviin laadullisiin haastattelututkimuksiin (tutkimuksen toinen osa), joista Itävalta, Luxemburg ja Ruotsi olivat menestyksekkäitä kampanjoinnissaan, kun taas Islanti, Suomi ja Alankomaat eivät olleet menestyksekkäitä (Ekengren ja Möller 2020b).

Yllä kuvatun tutkimusprojektin ensimmäisen osan yhteenvetona voidaan lyhyesti esittää, että vaihtuvan jäsenen paikan hakeminen turvallisuusneuvostossa tarkoittaa, oletetusti, valtioille 
mahdollisuutta ja halua vaikuttaa YK:n päätöksentekoon, halua ottaa kansainvälistä vastuuta tehdyistä päätöksistä, mahdollisuutta verkostoitumiseen ja tätä kautta mahdollisuutta nostaa omaa statustaan kansainvälisessä politiikassa. Kuitenkin, Länsi-Eurooppa ja muut maat -ryhmä näkee mahdollisuutensa verkostoitumiseen, päätöksentekoon vaikuttamiseen ja statuksensa kohottamiseen myönteisempänä kuin muut ryhmät. Samoin, kuten olettaa saattaakin, pienet valtiot näkevät turvallisuusneuvoston vaihtuvan jäsenen paikan vähäisempänä mahdollisuutena verkostoitumisen lisäämiseen tai oman statuksensa kohottamiseen kuin suuret valtiot. Kuitenkin Pohjoismaat, jotka yleisesti luetaan kuuluviksi pieniin valtioihin, luottavat mahdollisuuksiinsa tässä suhteessa. Pohjoismaat myös kehittävät normeja (engl. norm entrepreneurs) ja tätä kautta muistuttavat identiteetiltään keskisuuria valtioita ${ }^{7}$. Suomella, Luxemburgilla, Itävallalla, Ruotsilla ja Alankomailla oli kaikilla näkemys siitä, kuinka ne voivat olla myötävaikuttamassa YK:n kautta multilateralismin vahvistumiseen (Ekengren ja Möller 2020d).

Pohjoismaat eivät kuitenkaan ole homogeeninen ryhmä. Ruotsin odotukset ilmensivät keskisuuren valtion mahdollisuuksia vaikuttaa maailmanpolitiikkaan sekä multilateralismin ja omien diplomaattisten verkostojensa vahvistamista. Vaihtuvan jäsenen paikasta kilpailtaessa kyse on myös maan arvovallasta tai sen menettämisestä. Islannille kilpailu vaihtuvan jäsenen paikasta merkitsi valtiollisen suvereniteetin ilmentämistä: sillä on kapasiteettia ja kyvykkyyttä toimia turvallisuusneuvoston jäsenenä. Suomen motiivia voidaan kutsua "business as usual" -motiiviksi, sillä ehdokkuuden katsottiin olevan luonnollinen osa Suomen YK-politiikkaa, joka tietysti on osa Suomen ulko- ja turvallisuuspolitiikkaa. Ehdokkuutta ei missään vaiheessa kansallisessa keskustelussa kyseenalaistettu toisin kuin sekä Islannissa että Ruotsissa. Suomelle kyse oli myös osallistumisesta pohjoismaiseen rotaatioon ${ }^{8}$, jolloin siitä itsessään tuli myös motiivi osallistumiselle. Suomi haki rooliaan pienen ja keskisuuren valtion välillä pyrkien olemaan kokoaan suurempi (Ekengren ym. 2020).

Motiiveista saatettiin myös päätellä, kuinka ehdokkuus, lopputuloksesta riippumatta, tarjosi mahdollisuuden vahvistaa tai osoittaa kansainvälistä statusta: Islanti ja Luxemburg pieninä valtioina pyrkivät osallistumaan maailmanpolitiikkaan, Itävalta ja Alankomaat keskisuurina valtioina korostivat multilateralismia kun taas Suomi ja Ruotsi korostivat poliittista uskollisuuttaan YK:ta kohtaan (Ekengren ja Möller 2020d). Odotukset ja motiivit painottuivat kuitenkin hieman eri tavoin: turvallisuusneuvostokauden arvioidaan olevan hyödyllisempi suhteessa diplomaattiseen verkostoitumiseen ja statukseen kuin kykyyn olla merkityksellinen päätöksenteossa, vaikka motiiveissa ilmeneekin vahva halu vaikuttaa päätöksentekoon (emt.).

\section{MITEN MAAT KAMPANJOIVAT SAAVUTTAAKSEEN TURVALLISUUSNEUVOSTON VAIHTUVAN JÄSENEN PAIKAN?}

Tutkimuksen toinen osa käsittelee kysymyksiä miten valtiot toteuttavat kampanjansa ja miksi toiset kampanjat ovat menestyksellisempiä kuin toiset. Puolistrukturoidut laadulliset haastattelut tehtiin menestyksellisten ja ei-menestyksellisten YK:n turvallisuusneuvostovaalikampanjoijien kanssa. Niiden kohteiksi valikoituivat tutkimusparit Islanti ja Itävalta (Thorhallsson ym. 2020) Suomi ja Luxemburg (Piiparinen ym. 2020) sekä Ruotsi ja Alankomaat (Ekengren ja Möller 2020c). 
Tämän osan teoreettinen viitekehys rakentuu kolmen ulottuvuuden tai kampanjalogiikan kautta (Ekengren ja Möller 2020b), jotka ohjaavat tutkimusaineiston analyysia. Menestyksellisessä kampanjoinnissa on kyse ehdokkaan aiemmista ja nykyisistä toimista, osallistumisesta YK:n toimintaan, multilateraalisista meriiteistä ilmentäen maan hyvää "YK-CV:tä", eli sitä, miten ne ovat myötävaikuttaneet kansainvälisen rauhan ja turvallisuuden ylläpitämiseen, toisin sanoen osoittaneet resursseja YK:lle (engl. demonstrating contributions). Toinen keskeinen ulottuvuus koskee YK:n arvoihin, toimintaan ja haasteisiin sitoutumisen tärkeyttä (engl. providing ideational commitment) ja kolmas ulottuvuus pätevyyden ja kyvykkyyden osoittamista (claiming competence). Relevantti osaaminen liittyy niihin arvoihin, teemoihin ja haasteisiin, jotka ilmenevät niin sanotuissa kampanjaviesteissä, jotka edelleen auttavat näkemään kandidaatin kontribuution YK:n toimintaan (emt.).

Tässä tekstissä keskitytään esittelemään Suomea ja Luxemburgia käsittelevää tutkimusta. Tutkimus toteutettiin vertailevan analyysin (ks. esim. Azarian 2011, 113-125) sekä puolistrukturoitujen kvalitatiivisten haastattelujen avulla (ks. esim. Warren 2001, 83-103). Puolistrukturoidut haastattelut mahdollistivat kampanjaan osallistuneiden henkilöiden henkilökohtaisten kokemusten keräämisen. Vertaileva analyysi antoi tietoa kampanjoiden rakenteellisista tekijöistä. Tutkimusta varten haastateltiin ${ }^{12}$ luottamuksellisesti kahtatoista suomalaista ja luxemburgilaista virkahenkilöä, diplomaattia ja poliitikkoa, jotka olivat eri tavoin osallistuneet kampanjoihin. Haastattelut tehtiin henkilökohtaisesti, puhelimitse tai Skype-yhteyden välityksellä maaliskuun ja kesäkuun 2018 välisenä aikana ${ }^{13}$. Useimmat lähetetyt haastattelukutsut hyväksyttiin epäröimättä, mutta muutamat haastateltavaksi pyydetyt myös kieltäytyivät haastattelusta. Haastateltavat puhuivat haastatteluteemoista laajasti ja avoimesti ja olivat halukkaita jakamaan kokemuksiaan.

\section{RESURSSIEN OSOITTAMINEN - MITÄ TARJOTTAVAA SUOMELLA JA LUXEMBURGILLA OLI YK:LLE}

Suomi ja Luxemburg pyrkivät osoittamaan resurssejaan YK:lle hyvin eri tavoin. Luxemburg korosti kampanjaviesteissään senhetkisiä kontribuutioitaan YK:lle, kun taas Suomi nosti esiin historiaansa YK-toimijana etenkin rauhanturvaamisen saralla. Suomen "YK-CV" on tältä osin ollut hyvä, mutta Suomen päätös korostaa menneitä tekojaan kampanjassaan saattoi osoittautua jopa haitalliseksi. YK:n jäsenvaltiot olisivat mieluummin halunneet kuulla, miten Suomi toimisi mahdollisena turvallisuusneuvostokautenaan, kuten haastatteluissamme ilmeni.

Erilaiset ajalliset painotukset ilmenivät myös maiden kampanjointia varten tehdyissä kampanjaesitteissä. Suomen kampanjaesite keskittyy esittelemään Suomen historiaa YK-toimijana esimerkiksi korostamalla lukuja YK-operaatioihin lähetetyistä rauhanturvaajista (Finland to the UN Security Council in 2013-2014, 2-4). Suomi halusi ilmentää kyvykkyyttään toimia rauhanturvaamisen ja -välityksen pioneerina sekä eräänlaisena normien asettajana, kuten keskisuurille valtioille on tyypillistä. Esitteessä ei kuitenkaan mainita kampanjavuosien aikaisia lukuja Suomen kontribuutioista rauhanturvaamis- ja kriisinhallintatehtäviin, mikä johtunee siitä, että luvut olivat hyvin alhaisia. Suomen itsestään antama kuva oli siis nostalginen, menneisyyteen katsova sekä tämän takia hämmentävä. 
Luxemburg sen sijaan nosti kampanjaesitteessään esiin tuoretta numeraalista dataa ja todistusaineistoa kontribuutioistaan YK:lle. Luxemburgin kampanjaesite osoittaa selkeästi, kuinka maan kontribuutiot YK:n yleisbudjettiin ja rauhanturvaamisen budjettiin ovat YK:n jäsenvaltioiden suurimpia, kun maita tarkastellaan suhteessa väkilukuun (Luxembourg and the United Nations 2013-2014, 6-7.). Esite myös korostaa maan voimakasta panostusta kehitysyhteistyöhön (ODA, official development assistance), joka oli vuonna 2010 1,05 \% maan BKT:sta (emt., 7). Suomen esitteessä taas mainitaan Suomen kehitysyhteistyöpanosten vievän Suomea kohti YK:n 0,7 \%:n tavoitetta ${ }^{14}$ (Finland to the UN Security Council in 2013-2014, 8), mutta tuota tavoitetta Suomi ei koskaan saavuttanut. Luxemburgin ei siis tarvinnut lupailla kontribuutioidensa nostamista, vaan saattoivat puhua jo antamastaan tuesta. Sanomatta sitä suoraan, Luxemburg todisti olevansa pientä kokoaan suurempi toimija YK:ssa, kun taas Suomen viesti kieli siitä, että kenties aiemmin Suomi oli ollut merkittävä kontribuoija.

Esitteet kertovat maista hyvin erilaista tarinaa. Luxemburg esittää itsensä aktiivisena ja vastuita laaja-alaisesti kantavana YK-yhteisön toimijana. Suomi sen sijaan keskittyy historiaansa ja näyttäytyy jopa ajankohdan kontekstista irrallisena toimijana. Suomen toimijuus ei yhdisty yhtä vahvasti YK-yhteisöön kuin Luxemburgin.

Luxemburg rakentaa maakuvaansa paitsi sanoin, myös tuoreen kuva-aineiston kautta. Esitteen kuvat näyttävät luxemburgilaisia aktiivisia toimijoita erilaisissa YK-konteksteissa, mikä tukee esitteen tarinaa Luxemburgista YK:n toimintaan ja arvoihin sitoutuneena jäsenvaltiona. Luxemburgin sitoutuneisuus YK:hon tiivistyy esitteen kannessa, jossa on kuvattu Luxemburgin YK:lle lahjoittama veistos, The Knotted Gun. Tämä YK:n päämajan pihassa sijaitseva rauhan symboli ilmentää Luxemburgin sitoutumisesta järjestöön sen perustajajäsenenä. Sekä veistoksen että muun kuvamateriaalin kautta Luxemburg muistuttaa siitä, että se on luotettava ja sanojensa takana seisova jäsenvaltio, joka suhteessa kokoonsa panostaa mittavasti resursseja järjestön toimintaan.

Myös Suomen esitteessä on muutamia, osin ajallisesti varsin vanhoja kuvia, jotka ilmentävät Suomen toimijuutta, mutta suurin osa kuvakielestä keskittyy kuvaamaan Suomea hyvin perinteisellä tavalla koivikkojen, peltomaiseman tai lumisten metsien avulla - kuitenkaan sen enempää korostamatta suomalaisia ympäristöarvoja. Toisaalta esite näyttää Suomesta täysin irrallisia kuvia, kuten kehitysyhteistyön kohdemaissa kuvattuja otoksia. Verrattuna Luxemburgiin Suomi jää toimijana etäiseksi. Suomen esite on Luxemburgin ajantasaiseen ja konkreettiseen esitteeseen verrattuna taaksepäin katsova, vanhanaikainen ja romantisoituun Suomi-kuvaan nojaava idealistinen narratiivi, joka kertoo tavoitteista, ei konkreettisista toimista.

Sekä Suomella että Luxemburgilla oli käytössään suhteellisen saman mittaluokan rajalliset kampanjabudjetit sekä pienet kampanjaorganisaatiot. Vaikka valtioiden kampanjoiden lähtökohdat olivat samankaltaiset, poikkesivat niiden kampanjaprosessit, -organisaatiot ja -logiikat huomattavasti toisistaan.

Siinä missä Luxemburg aloitti aktiivisen kampanjatyön heti, joutui Suomi odottamaan pohjoismaisen rotaation vuoksi. Luxemburg hyödynsi seitsemän vuotta pidemmän kampanja-aikansa keräämällä äänestyslupauksia ja tekemällä vastavuoroisia äänestyssopimuksia. Moni maa lupasikin tukensa Luxemburgille jo aikaisessa vaiheessa. Myös Suomelle tarjottiin tukea jo kampanjan alkuvaiheessa, mutta Suomi ei vastannut ehdotuksiin. Suomen varhaista kampanjavaihetta kuvattiin varovaiseksi ja passiiviseksi, eikä esimerkiksi vastavuoroisia äänestyssopimuksia 
tehty riittävän aikaisin. Ainakin kymmenen maan kerrottiin olleen halukkaita äänestämään Suomea, mutta olivat luvanneet äänensä jo toisaalle Suomen vastatessa pyyntöön vastavuoroisesta äänestyslupauksesta.

Luxemburg jatkoi kampanjointiaan aivan viime minuuteille tulosten julkistukseen saakka. Luxemburg kampanjoi myös toisen ja mahdollisesti seuraavien äänestyskierroksen äänien saamiseksi, mikäli sitä ei valittaisi ensimmäisellä äänestyskierroksella - kuten Luxemburgille ja Suomelle tapahtui. Suomi sen sijaan kampanjoi ainoastaan ensimmäisen kierroksen äänistä, eikä keskusteluja käyty siitä, mitä valtiot tekisivät mahdollisella toisella kierroksella.

Suomi sai kampanjaansa läheistä tukea muilta Pohjoismailta, mutta yhteistyön syvyys ei riittänyt kompensoimaan Luxemburgin vastaavaa viiteryhmää: osana la Francophonieta Luxemburgilla oli erinomainen yhteys sen 88 ranskankieliseen valtioon ja hallitukseen.

Suomen ja Luxemburgin poliittiset asetelmat olivat hyvin erilaiset kampanjakauden aikana: siinä missä Suomella oli kampanjakauden aikana kuusi eri hallitusta, viisi eri pääministeriä ja neljä eri ulkoministeriä, oli Luxemburgilla kolme eri hallitusta, vain yksi pääministeri ja kaksi ulkoministeriä, joista toinen toimi ulkoministerinä lähes koko kampanjakauden ajan. Luxemburgin poliittinen stabiilius ei vaikuttanut ainoastaan politiikan, vaan myös kampanjan jatkuvuuteen, kun taas Suomi ei voinut välttyä epäjohdonmukaisuuksilta.

Pitkähköt turvallisuusneuvostokampanjat kietoutuvat osaksi valtioiden ulkopoliittista toimintaa sekä sen muotoiluun vaikuttavia sisäpoliittisia suhdanteita. Suomessa kampanjan suunnittelu aloitettiin ulkoministeriön ohjausryhmässä, joka lakkautettiin erillisen kampanjayksikön (POL-TN) perustamisen myötä vuonna 2009. Suomella oli siis kaksi eri kampanjaorganisaatiota 11 kampanjavuoden aikana. POL-TN:n vetämää kampanjaa toteutettiin Helsingistä käsin, mutta myös Suomen pysyvä edustaja YK:ssa oli aktiivisesti mukana kampanjassa. Vaikka muilta suomalaisilta suurlähettiläiltä pyydettiin näkemyksiä ja tietoa, ei erään haastateltavan mukaan entisiä suurlähettiläitä suuremmin hyödynnetty kampanjassa, vaikka tukea jopa tarjottiin kampanjayksikölle.

Luxemburgin kampanjaorganisaatio taas pysyi lähes samana alusta asti, ja Luxemburgille kampanjan jatkuvuus oli selkeä etu. Ensimmäisten kampanjavuosien aikana kampanjatyötä tehtiin Luxemburgista käsin, jonka jälkeen kampanjoinnin koordinointi siirtyi New Yorkiin. Koska Luxemburgin diplomaattinen verkosto oli rajallinen, oli tämä viisas strateginen päätös. Luxemburg teki myös toisen taktisen päätöksen: kampanjaa vetänyt suurlähettiläs toteutti kampanjatyötä vain New Yorkissa.

Sekä Suomi että Luxemburg hyödynsivät kampanjassaan korkean tason poliitikkoja sekä muita toimijoita, mutta Luxemburg käytti tehtäväänsä sitoutuneita poliitikkojaan erityisen taitavasti. Monet kokivat, että vastaava jatkuva poliittinen sitoutuminen puuttui Suomen kampanjasta.

Suomessa korkean tason poliitikot olivat mukana kampanjassa, mutta kampanjatoimijoiden kesken oli selvästi havaittavissa erilaisia näkemyksiä siitä, tulisiko kampanjan olla poliitikko- vai virkahenkilövetoinen. Koska Suomen kampanja oli vahvasti virkahenkilöstön ohjaama, siitä ei tullut korkean tason poliittista hanketta.

Luxemburgilla oli havaittavissa erittäin vahva kansallinen motivaatio päästä turvallisuusneuvostoon sekä selkeä viesti ja suunnitelma siitä, mitä maa neuvostossa edustaisi ja ajaisi. Suomen ehdokkuuden ja jopa valinnan näkeminen itsestäänselvyytenä voi olla yksi syy kansallisen motiivin ja poliittisen tason sitoutumisen puutteelle, jonka moni haastateltava nosti esiin. 


\section{IDEATIONAALINEN SITOUTUNEISUUS - IHMISOIKEUKSIA JA MUITA ARVOJA}

Vaikka molemmilla valtioilla oli sama tavoite ja samankaltainen tausta väkiluvullisesti pienenä EU-jäsenvaltiona, havainnollistivat Suomi ja Luxemburg sitoutumistaan YK:n arvoihin hyvin eri tavoin. Kokonaisuudessaan Suomen kampanjaviestit olivat epäjohdonmukaisia ja vaatimattomia verrattuna Luxemburgin viesteihin. Kysyttäessä suomalaiset haastateltavat eivät kyenneet nimeämään Suomen kampanjan keskeisiä teemoja, kun taas Luxemburgin edustajilla oli selkeä näkemys siitä, mitä asioita kampanjoidessa korostettiin.

Tappionsa jälkeen Suomen ulkoministeriö teetti itsenäisen tutkimuksen turvallisuusneuvostovaaleista Kansainvälisellä rauhaninstituutilla (International Peace Institute; IPI). IPI:n tutkimuksen (2013) mukaan liiallinen ihmisoikeuksien ja sukupuolten välisen tasa-arvon painottaminen vaikutti Suomen tappioon. Lisäksi Suomen asennetta muita valtioita kohtaan kuvattiin ylimieliseksi ja "besserwissermäiseksi". Tutkimuksessamme kuitenkin esitämme, että todellisuudessa Luxemburg painotti kampanjassaan ihmisoikeuksia huomattavasti Suomea enemmän. Luxemburgin kampanjaviestit ilmensivät selvästi globaalin oikeudenmukaisuuden kysymyksiä, mikä vahvisti Luxemburgin sanomaa.

Toisin kuin Suomen kampanjassa, Luxemburgin kampanjassa tehtiin tietoinen päätös pitää esillä myös poliittisesti herkkiä aiheita keskusteluissa YK:n jäsenvaltioiden kanssa, kuten ihmisoikeuksiin ja kansainväliseen rikosoikeuteen liittyviä kysymyksiä. Luxemburgin kampanjaorganisaatio oli tietoinen, että tämä oli riski kampanjalle, mutta näiden kysymysten nähtiin olevan keskeinen osa Luxemburgin ulkopolitiikkaa ja identiteettiä, jolloin niiden jättäminen keskusteluiden ulkopuolelle olisi ollut epärehellistä ja jopa haitannut kampanjaa. Suomi sen sijaan päätti olla korostamatta ihmisoikeuksia laajasti kampanjastrategiassaan. Tällä haluttiin juuri välttää ylimielistä "besserwisser"-maakuvaa, joka Pohjoismaihin saatettiin liittää. Yksi mahdollinen tulkinta on, että Suomi oletti muiden tuntevan maansa maineen ihmisoikeuksien ja naisten tasa-arvon edistäjänä. Luxemburg ei halunnut tässäkään suhteessa ottaa mitään annettuna.

Siinä missä Suomen suhtautuminen ihmisoikeuskysymyksiin kampanjassaan oli suhteellisen vaatimatonta, toi Luxemburg ihmisoikeuskysymykset esiin, paitsi osana kampanjastrategiaansa, myös, mikä tärkeintä, osana kansallista identiteettiään. Turvallisuusneuvostokampanjan avulla haluttiin kirkastaa mitä arvoja ja tavoitteita Luxemburg turvallisuusneuvostossa ajaisi ja minkä mukaan se myös äänestäisi. Koska Suomi varoi ihmisoikeustematiikan tuomista esiin kampanjassaan, ei se myöskään onnistunut antamaan tässä suhteessa selkeää kuvaa omasta toiminnastaan turvallisuusneuvoston jäsenenä. Kunkin maan antama ääni on salainen, mutta tämä todennäköisesti vaikutti erityisesti EU:n ja muiden länsimaiden äänestyskäyttäytymiseen.

\section{PÄTEVYYKSIEN OSOITTAMINEN - MILLAISTA KYVYKKYYTTÄ TURVALLISUUSNEUVOSTOSSA VAADITAAN}

Sekä Suomi että Luxemburg halusivat vakuuttaa muut jäsenvaltiot siitä, että ne olivat päteviä kantamaan turvallisuusneuvoston jäsenen vastuut ja velvollisuudet. Luxemburg osoitti kyvykkyyttään nostamalla esiin aiemmat kansainväliset vastuutehtävänsä, esimerkiksi EU:n puheen- 
johtajuudet. Suomi oli jo kahdesti toiminut turvallisuusneuvoston vaihtuvana jäsenenä. Molemmilla oli siis näyttöjä vastuullisista kansainvälisistä tehtävistä.

Baldur Thorhallssonin $(2012,159)$ mukaan pienet valtiot voivat osoittaa kykynsä olla merkityksellisiä turvallisuusneuvostossa kahdella eri tavalla: Ensinnäkin ne voivat ilmentää sisäistä tai hallinnollista kyvykkyyttään esimerkiksi poliitikkojen ja diplomaattien tietämyksen, aloitteellisuuden sekä diplomaattisten tai johtajuustaitojensa kautta. Toisekseen pienet valtiot voivat ilmentää ulkoista kyvykkyyttään esittämällä itsensä puolueettomana toimijana tai normien asettajana.

Luxemburgin voidaan sanoa ilmentäneen sisäistä kyvykkyyttään tehokkaammin ja onnistuneemmin esimerkiksi YK-diplomaattien johtotehtävissä YK-elimissä. Suomi keskittyi näyttämään ulkoista kyvykkyyttään, etenkin rauhanturvaamisen ja -välityksen kautta. Keskittyminen ulkoisen kyvykkyyden todistamiseen kuitenkin tuotti ristiriitaista maakuvaa.

Molemmat valtiot pyrkivät ilmaisemaan sisäistä kyvykkyyttään poliitikkojensa ja virkahenkilöidensä diplomaattisen osaamisen kautta, mutta haastateltavien mukaan Luxemburg oli tässä aktiivisempi ja tehokkaampi ja täten onnistuneempi. Haastateltavien mukaan luxemburgilaisilla poliitikoilla ja diplomaateilla oli erityisen hyvät sosiaaliset ja kansainvälisessä vuorovaikutuksessa vaadittavat verkostoitumistaidot. Lisäksi laajoja henkilökohtaisia verkostoja hyödynnettiin kampanjassa.

Vaikka Suomessa poliittista vastustusta kampanjalle ei ollut, oli poliittisen tason sitoutuminen kampanjaan matala. Siinä missä Suomessa ehdokkuus oli osa normaalia YK- ja ulkopolitiikkaa ja yksi tehtävä muiden joukossa, Luxemburgissa ja Australiassa ehdokkuus oli kansallinen prioriteetti, ja korkean tason poliitikot sitoutuivat kampanjaan sen mukaisesti.

Haastatteluissa nousi esiin kritiikki Suomen kampanjaorganisaation rakennetta kohtaan, sillä organisaatiossa ei ollut lainkaan naisia keskeisissä rooleissa, vaikka Suomi onkin profiloitunut tasa-arvon edelläkävijänä. Monet haastatelluista eivät kuitenkaan nähneet tätä ongelmana. Kuitenkin se, että Luxemburgin kampanjaa veti varsin arvostettu nainen, antoi Luxemburgin kampanjalle myönteistä huomiota. Lisäksi siinä missä Suomi hyödynsi kampanjatoimissaan yhtä kampanjaorganisaation ulkopuolista, Karibian alueella toiminutta suurlähettilästä, oli Luxemburgilla neljä alueellista erityislähettilästä. Ottaen huomioon, että Karibian valtioiden yhteisö, CARICOM, asettui vaaleissa Suomen taakse, voi suurlähettilään kampanjatoimista nähdä olleen hyötyä. Erityislähettiläiden käyttäminen ilmensi Luxemburgin tietoista panostusta maantieteellisiin alueisiin, joilla niiden diplomaattiset verkostot olivat ohuita - aivan kuten Suomellakin.

Vaikka monet suomalaiset haastateltavat sanoivat Suomen esittäneen kampanjassa itsensä pienenä valtiona, osoittaa tutkimuksen analyysi Suomen ilmentäneen itseään myös keskisuurena valtiona etenkin rauhanturvaamisen ja -välityksen osalta. Suomen maakuva oli siis jokseenkin moninainen, kun taas Luxemburg onnistui antamaan itsestään selkeän ja johdonmukaisen kuvan sekä valtiona että toimijana turvallisuusneuvostossa.

\section{PÄÄTELMIÄ}

Tekemämme analyysi toi esiin Suomen turvallisuusneuvostokampanjassa olleet epäjohdonmukaisuudet. Suomi ilmensi itseään keskisuurena valtiona, globaalina rauhanvälitykseen ja rauhanturvaamiseen liittyvien normien uudistajana ja kehittäjänä. Tämä ei kuitenkaan vastannut 
senhetkistä tilannetta. Suomen osallistuminen rauhanturvaamiseen oli kampanjoinnin ajankohtana historiallisen alhainen, samoin kuin Suomen virallinen kehitysyhteistyöpanostus verrattuna Luxemburgiin. Tämä tarkoitti, ehkä tahattomastikin, että Suomi ilmaisi itseään sekä pienenä että keskisuurena valtiona. Suomen pyrkimys esiintyä kokoaan suurempana jäi ilman perusteita. Suomen tuleekin tehdä "YK-CV:nsä" huomattavasti paremmaksi seuraavan turvallisuusneuvostokauden 2029-2030 kampanjaa varten.

Toinen, edelliseenkin liittyvä johtopäätös koskee Suomen ulko- ja turvallisuuspolitiikkaan liittyviä rakenteellisia tekijöitä. YK ei ole ollut keskeisellä sijalla Suomen ulko- ja turvallisuuspolitiikassa kylmän sodan päättymisen jälkeen eikä kampanja saanut riittävää painoarvoa ulkopoliittisissa toimissa. Kolmantena johtopäätöksenä voidaan todeta Suomen epäonnistumisen olleen suhteessa myös Luxemburgin vahvaan kampanjaan. Korkean tason poliittiset päättäjät olivat aktiivisesti Luxemburgin kampanjassa mukana, ja kampanja kokonaisuudessaan oli tehokas, hyvin suunniteltu ja kampanjan viesti selkeä. Tämä saavutti näkyvyyttä New Yorkissa, minkä lisäksi Luxemburgilla oli korkean tason luottamustehtäviä YK:n instituutioissa. Näiden ansiosta Luxemburg saavutti hyvän kontaktin jäsenvaltioihin New Yorkissa. Luxemburgin kampanja oli kansallinen projekti, joka oli Luxemburgin ulkopolitiikan tärkein tavoite Suomen kampanjan ollessa "business as usual".

Neljäntenä päätelmänä esitetään, kuinka tutkimus ei tue sitä esitettyä väitettä, että liiallinen keskittyminen ihmisoikeuksiin ja naisten tasa-arvokysymyksiin ja tätä kautta eräänlaisena "besserwisserina" toiminen olisi ollut Suomen kampanjalle haitallista. Tämän tutkimuksen perusteella voi esittää, että Suomi itse asiassa piti ihmisoikeustematiikan taka-alalla kampanjassaan, kun taas Luxemburgin kampanjassa korostuivat voimakkaasti ja johdonmukaisesti suojeluvastuu, ihmisoikeudet, naisten oikeudet, demokratia, oikeusvaltioperiaate sekä globaali oikeudenmukaisuus.

Käsitys siitä, että Suomi ei menestynyt kampanjassaan sen vuoksi, että korosti liiallisesti ihmisoikeuksia, juontuu IPI:n johtajan Terje Röd-Larsenin näkemyksestä:

The core values which the Nordics stand for [...] like human rights, the rule of law, the responsibility to protect, et cetera, is (sic) not necessarily that popular amongst the majority of the membership in the United Nations. And this is paired with a perception that the Nordics consider themselves to be morally superior, that there is a "besserwisser", condescending attitude towards others based on the values and ideological issues. (YLE 2013)

Monet suomalaiset päättäjät ja tutkijat ovat hyväksyneet raportin sellaisenaan, mutta haastatteluissa sen väitteitä myös kyseenalaistettiin. Röd-Larsenkin totesi, että Suomi ei ole kuitenkaan kaikkein syyllisin moraaliseen ylemmyyteen (emt.). Tästä näkökulmasta tarkasteltuna kiinnostavaa on, kuinka Suomen moraalinen ylemmyys olisi ollut keskeinen syy kampanjan epäonnistumiselle ja miksi tämä selitys kuitenkin niin laajasti Suomessa hyväksyttiin (YLE 2012a; 2012b). Eräs selitys tällaiselle ajatukselle voisi löytyä empiirisen virhepäätelmän (engl. empiricist fallacy) käsitteestä (Bhaskar 1997, 34), jolla tarkoitetaan harhaanjohtavaa päätelmää, joka perustuu muihin samankaltaisiin tapahtumiin.

Empiirinen virhepäätelmä tarkoittaa tässä taipumusta selittää Suomen turvallisuusneuvostokampanjan epäonnistuminen viittaamalla samankaltaisiin YK:n äänestystuloksiin ennen vuotta 
2012: Islannin epäonnistunut tavoite päästä turvallisuusneuvoston jäseneksi 2008 ja Ruotsin epäonnistunut Ihmisoikeusneuvostokampanja vuonna 2012 Suomen epäonnistumisen jälkeen (ks. esim. UM 2013). Tällainen empiirinen virhepäätelmä on enemmänkin inhimillinen reaktio epäonnistuneeseen kampanjaan hyvistä aikomuksista ja pyrkimyksistä huolimatta.

Tämä tutkimus osoittaa, että yhden vahvan ja selkeän syyn sijaan useat eri tekijät yhdessä selittävät Suomen kampanjan epäonnistumista. Tämän tutkimuksen perusteella voidaan esittää, kuinka vahva ihmisoikeuksien ja oikeusvaltioperiaatteen korostaminen on tärkeää pohjoismaisille valtioille niiden kampanjoidessa turvallisuusneuvoston jäsenyydestä. Tämä on linjassa paitsi niiden omien, myös YK:n arvojen kanssa. Toinen tärkeä ulottuvuus on korostaa maan identiteetin ja kampanjaviestin selkeyden tärkeyttä. Edelleen, vaalitulosta ei voi ottaa annettuna ja kampanjassa on hyvä olla olemassa varasuunnitelma, mikäli valtio ei tule valituksi ensimmäisellä kierroksella.

Norja valittiin turvallisuusneuvostoon kesäkuussa 2020 kaudeksi 2021-2022 yhdessä Irlannin kanssa. Norja korosti kampanjassaan sitoutumistaan multilateralismiin, ihmisoikeuksiin, siviilien suojeluun, kansainväliseen oikeuteen sekä kestävän kehityksen, rauhan ja turvallisuuden keskinäistä yhteyttä. Norja on YK:n parhaita kehitysyhteistyön ja humanitaarisen toiminnan, rauhan ja turvallisuuden agendan tukijoita (SCR 2020). Norjan "YK-CV" on kunnioitettava. Tämä ei tue IPI:n raportin näkemystä moraalisen ja eettisen toiminnan pulmallisuudesta.

Suomen epäonnistumista ei siis voida esittää besserwisseriyden, liian liberaalien arvojen tai pohjoismaisuuden syyksi. Sen sijaan Suomen kampanjan epäonnistumisen voidaan nähdä juontavan myöhäisiin kampanjatoimiin, ristiriitaiseen maakuvaan, epäselviin kampanjaviesteihin, -teemoihin ja -motiiviin, "business as usual" -asenteeseen, kampanjan vähäiseen poliittiseen merkitykseen sekä kilpailijoiden erinomaiseen suoriutumiseen.

\section{VIITTEET}

1. [...] jolloin sen on ensisijaisesti kiinnitettävä erityistä huomiota Yhdistyneiden Kansakuntien jäsenten osuuteen kansainvälisen rauhan ja turvallisuuden ylläpitämisessä ja järjestön muiden päämäärien edistämisessä sekä myös tasapuoliseen maantieteelliseen jakautumiseen. [...] (YK:n peruskirja, 23, 1 art.) Uudet jäsenet valitaan seuraavista alueellista ryhmistä: Afrikka, Aasia ja Tyyni valtameri, Latinalainen Amerikka ja Karibia, Itäinen Eurooppa sekä Länsi-Eurooppa ja muut maat. Ryhmien sisällä voi vallita kilpailutilanne (engl. contested) tai konsensus (uncontested) jaettavista paikoista. Ks. Security Council Report (2012).

2. Ks. esim. Security Council Report 2012, 7-8. Tähän ryhmään kuuluu 28 jäsentä, Länsi-Euroopan lisäksi ryhmään kuuluvat Australia, Kanada ja Uusi-Seelanti ("muut maat") sekä Israel vuodesta 2000. Ryhmässä on seuraavat alaryhmät: Pohjoismaat, CANZ (Kanada, Australia, Uusi-Seelanti) ja Benelux (Belgia, Luxemburg, Alankomaat). Pohjoismaiden ja CANZ-alaryhmissä jäsenet tukevat toistensa kampanjoita. Benelux-maat eivät koordinoi kampanjoitaan.

3. Ruotsi valittiin suoraan ensimmäisellä äänestyskierroksella. Italia ja Alankomaat eivät kumpikaan saaneet viiden äänestyskierroksen jälkeen tarvittavaa äänimäärää, joten ne jakoivat kauden keskenään. (Ks. esim. YK 2016.) 
4. Ensimmäisellä äänestyskierroksella Turkki sai 151 ja Itävalta 133 ääntä tullen valituiksi (ks. esim. Security Council Report 2012, Annex 3).

5. Tutkimuksen teoreettinen viitekehys esitetään tarkemmin vielä julkaisemattoman käsikirjoituksen luvussa 2 (Ekengren ja Möller 2020b).

6. Tutkimuksesta ja sen tämän osan suorittamisesta tarkemmin, ks. Ekengren ym. 2020.

7. Pieniä ja keskisuuria valtioita on määritelty eri tavoin (ks. esim. Thorhallsson ja Wivel 2006; Thorhallsson 2018; Robertson 2017). Asiaa voi kuitenkin havainnollistaa siten, että keskisuurilla valtioilla on usein normatiivisia tavoitteita, ne pyrkivät toimimaan sillanrakentajina alueellisissa konteksteissa ja kansainvälissä järjestöissä tavoitteenaan vaikuttaa maailmanpolitiikkaan. Mikäli valtiolla on pienen tai keskisuuren valtion identiteetti, niiden tulisi toimia ja niitä tulisi kohdella sen mukaisesti. (Ekengren ja Möller 2020b.)

8. Pohjoismaat eivät koskaan kilpaile keskenään, mikä tarkoittaa, että kulloinkin on vain yksi pohjoismainen ehdokas keskinäisen rotaatiosuunnitelman mukaisesti. Pohjoismaat tukevat toistensa ehdokkuuksia ja mahdollisuuksien mukaan osallistuvat toistensa kampanjointiin, jotka on ajallisesti organisoitu niin, ettei kilpailutilannetta synny. Suomi esimerkiksi siirsi oman kampanjansa aloittamista siihen saakka, kunnes Islannin kampanja oli päättynyt. Ekengren ja Möller (2020a) ovat arvioineet, kuinka tämä YK-vaaleihin liittyvä käytäntö ilmentää Pohjoismaiden jaettua identiteettiä sekä strategista näkemystä siitä. Tämä parantaa maiden mahdollisuuksia edistää yhteisiä intressejä, mikäli ne koordinoivat toimiaan ja tukevat toistensa pyrkimyksiä.

12. Haastattelut teki YTM, HuK Anni Tervo.

13. Viitteet haastatteluihin julkaisemattoman käsikirjoituksen luvuissa 3 (Ekengren ym. 2020) ja 5 (Piiparinen ym. 2020). Joihinkin haastatteluihin tehtiin täydennyksiä kesällä 2019. Haastattelut on nauhoitettu ja litteroitu.

14. "The Finnish Government will ensure that its development co-operation appropriations take Finland towards the level of 0.7 per cent of gross national income set by the United Nations".

\section{LÄHTEET}

Azarian, Reza. 2011. Potentials and Limitations of Comparative Method in Social Science. International Journal of Humanities and Social Science 1:4, 113-125.

Bhaskar, Roy. 1997. A Realist Theory of Science. 2. painos. Lontoo: Verso.

von Einsiedel, Sebastian ja Louise Bosetti. 2016. Realizing the UN's Protection Promise: A Central Challenge for the Next Secretary-General. Global Responsibility to Protect 8, 366-389.

https://doi.org/10.1163/1875984-0080400.

Ekengren, Ann-Marie, Hjorthen, Fredrik Dybfest, Möller, Ulrika, Piiparinen, Touko, Seppä, Tarja, Tervo, Anni, Thorhallsson, Baldur, Elínardóttir, Jóna Sólveig ja Anna Maria Eggertdóttir. 2020. Why do states want a seat on the UNSC? Julkaisematon käsikirjoitus osana projektia Ann-Marie Ekengren ja Ulrika Möller (toim.), The Quest for Power in International Politics: Campaigns by and Selection of Non-Permanent Members to the UNSC, luku 3.

Ekengren, Ann-Marie ja Ulrika Möller 2020a. The relevance of a non-permanent seat in the United Nations Security Council. Julkaisematon käsikirjoitus osana projektia Ann-Marie Ekengren ja Ulrika 
Möller (toim.), The Quest for Power in International Politics: Campaigns by and Selection of NonPermanent Members to the UNSC, luku 1.

Ekengren, Ann-Marie ja Ulrika Möller 2020b. Competing for an Elected Seat in the Security Council: Why and How? Julkaisematon käsikirjoitus osana projektia Ann-Marie Ekengren ja Ulrika Möller (toim.), The Quest for Power in International Politics: Campaigns by and Selection of Non-Permanent Members to the UNSC, luku 2.

Ekengren, Ann-Marie ja Ulrika Möller 2020c. Election 2016: Sweden and the Kingdom of Netherlands. Julkaisematon käsikirjoitus osana projektia Ann-Marie Ekengren ja Ulrika Möller (toim.), The Quest for Power in International Politics: Campaigns by and Selection of Non-Permanent Members to the UNSC, luku 6.

Ekengren, Ann-Marie ja Ulrika Möller 2020d. Results, Conclusions and Reflections. Julkaisematon käsikirjoitus osana projektia Ann-Marie Ekengren ja Ulrika Möller (toim.), The Quest for Power in International Politics: Campaigns by and Selection of Non-Permanent Members to the UNSC, luku 7.

Finland to the UN Security Council in 2013-2014. Ministry for Foreign Affairs of Finland.

IPI (International Peace Research Institute). 2013. Taking Stock, Moving Forward: Report to the Foreign Ministry of Finland on the 2012 Elections to the United Nations Security Council. https://www. ipinst.org/wp-content/uploads/2013/04/pdfs_130406-UNSC_Elections_Report_Final.pdf. Viitattu 10.7.2020.

Luxembourg and the United Nations. Candidate for the Security Council 2013 - 2014. Grand-Duché de Luxembourg. Ministère des Affaires étrangères.

Piiparinen, Touko, Seppä, Tarja ja Anni Tervo. 2020. Greater Than its Size? Comparing Finland's and Luxembourg's Campaigns to the Security Council. Julkaisematon käsikirjoitus osana projektia AnnMarie Ekengren ja Ulrika Möller (toim.), The Quest for Power in International Politics: Campaigns by and Selection of Non-Permanent Members to the UNSC, luku 5.

Robertson, Jeffrey. 2017. Middle-power definitions: confusion reigns supreme. Australian Journal of International Affairs 71:4, 355-370. https://doi.org/10.1080/10357718.2017.1293608

SCR (Security Council Report). 2012. Security Council Elections 2012. Special Report. No.1. September. http://securitycouncilreport.org. Viitattu 9.7.2020.

SCR (Security Council Report). 2020. Security Council Elections 2020. Research Report. No.2. 29 May. http://securitycouncilreport.org. Viitattu 9.7.2020.

Thorhallsson, Baldur ja Anders Wivel. 2006. Small States in the European Union: What Do We Know and What Would We Like To Know? Cambridge Review of International Affairs 19:4, 651-668. https://doi.org/10.1080/09557570601003502.

Thorhallsson, Baldur. 2012. Small States in the UN Security Council: Means or Influence? The Hague Journal of Diplomacy 7, 135-160. https://doi.org/10.1163/187119112X628454.

Thorhallsson, Baldur. 2018. Studying Small States: A Review. Small States \& Territories 1:1, 17-34.

Thorhallsson, Baldur, Elínardóttir, Jóna Sólveig ja Anna Maria Eggertdóttir. 2020. Competing Small Powers: Austria versus Iceland in the UNSC. Julkaisematon käsikirjoitus osana projektia Ann-Marie Ekengren ja Ulrika Möller (toim.), The Quest for Power in International Politics: Campaigns by and Selection of Non-Permanent Members to the UNSC, luku 4.

UM (Ulkoasiainministeriö). 2013. Minister Tuomioja's Speech in Seminar on Nordic Values in the UN. Speeches. 13.9.2013. https://um.fi/speeches/-/asset_publisher/up7ecZeXFRAS/content/ulkoministerituomiojan-puhe-pohjoismaisesta-yk-yhteistyosta. Viitattu 10.7.2020. 
Warren, Carol A.B. 2001. Qualitative Interviewing. Teoksessa Jaber F. Gubrium ja James A. Holstein (toim.), Handbook of Interview Research. Sage Publications, 83-103.

YK. 1945. Peruskirja. https://www.finlex.fi/fi/sopimukset/sopsteksti/1956/19560001/19560001_2. Viitattu 7.9.2020.

YK. 2012. United Nations General Assembly. Sixty-seventh session. A/67/PV.27 https://www.securitycouncilreport.org/atf/cf/\%7B65BFCF9B-6D27-4E9C-8CD3-CF6E4FF96FF9\%7D/a_67_pv_27.pdf. Viitattu 10.7.2020

YK. 2016. Elected to Security Council in Single Round of General Assembly Voting, Italy Says It Will Cede Non-Permanent Seat to Netherlands after 1 Year. Meetings Coverage and Press Releases, GA/11797. https://www.un.org/press/en/2016/ga11797.doc.htm. Viitattu 10.7.2020.

YLE. 2012. Niinistö: Pohjoismaiden on nähty röyhistelevän maailmalla omilla malleillaan. 1.12.2012. https://yle.fi/uutiset/3-6399235. Viitattu 2.12.2018.

YLE. 2012a. Niinistö: Suomella ei varaa ylemmyydentunteeseen. 23.12.2012. https://yle.fi/uutiset/3-6427568. Viitattu 2.12.2018.

YLE. 2013. US Think Tank: Not Everyone Cares for the Nordic "Know-It-All" Attitude. 9.4.2013. https://yle.fi/uutiset/osasto/news/us_think_tank_not_everyone_cares_for_the_nordic_know-it-all_ attitude/6571358. Viitattu 9.7.2020.

\section{KIRJOITTAJATIEDOT}

\section{TARJA SEPPÄ}

YTT, lehtori

Politiikan tutkimus/kansainvälinen politiikka

Tampereen yliopisto

tarja.seppa@tuni.fi

\section{ANNI TERVO}

YTM, HuK

anni.k.tervo@gmail.com 